\title{
ЕКСПЕРИМЕНТАЛЬНІ ДОСЛІДЖЕННЯ ТЕПЛОВОГО РЕЖИМУ ГІДРОТЕРМАЛЬНОЇ ТЕПЛОНАСОСНОЇ СИСТЕМИ
}

O.В. Зур'ян, канд. техн. наук

Інститут відновлюваної енергетики НАН України, 02094, вул. Гната Хоткевича, 20А, м.Київ, Україна

Грунтові води є високоефективним джерелом відновлюваної низкопотенциальной енергії, проте ефективне використання таких систем багато в чому залежить від попереднього вивчення геологічної будови гірського масиву, а також гідрогеологічних параметрів водоносного горизонту. Метою дослідження є визначання залежності техніко-економічних показників гідротермальної теплонасосної системи від гідрогеологічних параметрів водоносного горизонту. В роботі визначено основні гідрогеологічні параметри, які впливають на тепловий режим гідротермальної теплонасосної системи. Представлено розроблену і сконструйовану в Інституті відновлюваної енергетики НАН Украӥни гідротермальну експериментальну теплонасосну систему, яка складається з теплового насоса та двох свердловин, через які забезпечується циркуляція води від підземного горизонту до теплового насоса. Наведено опис характеристик вимірювального обладнання, встановленого на гідротермальній теплонасосній системі, та розробленої автором інтерактивної системи диспетчеризаиї на базі програмного продукту ESM (Engineering Systems Manager) 3 використанням язика програмування FBD (Function Block Diagram|Continuous Function Chart), яка була застосована для побудови системи візуалізачії та архівачії даних, отриманих в прочесі иієї науково-дослідницької роботи. Наведено результати проведених експериментальних досліджень. Виконано аналіз ефективності та інвестиційної привабливості гідротермальної системи, де як відновлюване первинне джерело теплової енергії для роботи теплового насоса використовується низькопотенціальна теплова енергія води водоносного горизонту. Показано, що наявні гідротермальні теплонасосні системи не завжди адаптовані до умов експлуатаиії, місия розташування об'єкта і що відсутня методика проєктування гідротермальних теплонасосних систем і методика проведення попередніх гідрогеологічних досліджень району, вибраного для монтажу даних систем. Мають перспективу подальші експериментальні дослідження впливу дебіту та динаміного рівня свердловини на стабільність та ефективність роботи гідротермальної теплонасосної системи. Бібл. 16, табл. 1, рис. 5.

Ключові слова: підземні води, тепловий насос, гідротермальна система, водоносний горизонт, низькопотенційна енергія $в о \partial u$.

\section{EXPERIMENTAL STUDIES OF THE THERMAL REGIME OF THE HYDROTHERMAL HEAT PUMP SYSTEM}

O. Zurian, candidate of technical science, senior researcher, Department of geothermal energy

Institute of Renewable Energy of the National Academy of Sciences of Ukraine

02094, 20A Hnata Khotkevycha St., Kyiv, Ukraine.

Groundwater is a highly efficient source of renewable low-potential energy, but the effective use of such systems depends largely on the preliminary study of the geological structure of the mountain range and the hydrogeological parameters of the aquifer. The aim of the study is to determine the dependence of technical and economic indicators of the hydrothermal heat pump system on the hydrogeological parameters of the aquifer. The main hydrogeological parameters that affect the thermal regime of the hydrothermal heat pump system are determined in the work. The hydrothermal experimental heat pump system developed and constructed at the Institute of Renewable Energy of the National Academy of Sciences of Ukraine is presented. It consists of a heat pump and two wells through, which water circulation from the underground horizon to the heat pump is provided. The method of conducting research is described. The description of the characteristics of the measuring equipment installed on the hydrothermal heat pump system and 
developed by the author of the interactive dispatching system based on the software product ESM (Engineering Systems Manager) using FBD programming language (Function Block Diagram/Continuous Function Chart), which was used to build the data system obtained in the process of conducting this research work. The results of the conducted experimental researches are given. The analysis of efficiency and investment attractiveness of the hydrothermal system is performed, where the low-potential thermal energy of the aquifer water is used as a renewable primary source of thermal energy for the heat pump operation. It is substantiated that the existing hydrothermal heat pump systems are not always adapted to the operating conditions and location of the facility and there is no method of designing hydrothermal heat pump systems, methods of preliminary hydrogeological studies of the area planned for installation of these systems. It is determined that further experimental studies of the influence of flow rate and dynamic level of the well on the stability and efficiency of the hydrothermal heat pump system are promising. Ref. 16, tab. 1, fig. 5.

Keywords: groundwater, heat pump, hydrothermal system, aquifer, low potential water energy

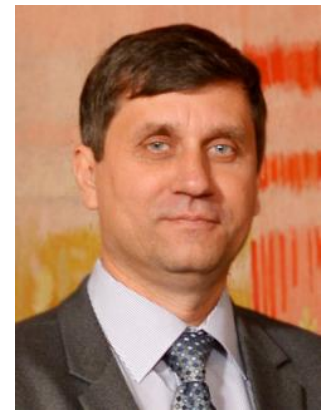

O.В. Зур'ян

O. Zurian
Відомості про автора: Науковий співробітник відділу геотермальної енергетики Інституту відновлюваної енергетики НАН України. Кандидат технічних наук

Освіта: Ставропольске вище військове інженерне училище зв'язку. Спеціальність «Інженер рідіозв'язку».

У 2016 році у Харківському національному університеті імені В.Н. Каразіна захистив дисертаційну роботу за темою «Екологічно безпечні відновлювані джерела отримання теплової енергії»

Наукова сфера: відновлювана енергетика нетрадиційні поклади вуглеводнів, екологічна безпека

Публікації: понад 70 наукових публікацій, в тому числі 3 монографії та 20 авторських патентів на винахід та корисну модель ORCID: 0000-0002-2391-1611

Контакти: +38(050)778-30-29

e-mail: alexey_zuryan@ukr.net
Author information: Researcher of the Department of Geothermal Energy of the Institute of Renewable Energy of the National Academy of Sciences of Ukraine.

Candidate of Technical Sciences.

Education: Stavropol Higher Military Engineering Academy of Communication. Specialty: engineer of radiocommunication. He defended his dissertation: "Environmentally safe renewable heat sources" in 2016 at V.N. Karazina Kharkiv National University Reasearch area: renewable energy, unconventional hydrocarbon deposits, environmental safety.

Publications: more than 70 scientific publications, including 3 monographs and 20 author's patents for inventions and utility models.

ORCID: 0000-0002-2391-1611

Contacts: $+38(050) 778-30-29$

e-mail: alexey_zuryan@ukr.net
Перелік використаних позначень та скорочень:

ГеоТС - геотермальна теплонасосна система;

ГідроТС - гідротермальна теплонасосна система;

ТН - тепловий насос;

ТРВ - терморегулювальний вентиль;

ПЗ - програмне забезпечення;

Вступ. Останніми роками все більшого практичного значення набуває використання відновлюваної низькопотенційної енергії приповерхневих шарів Землі на глибинах від 20 до 300 м за допомогою теплових насосів. Ї̈̈ застосування для теплопостачання окремих будинків, виробничих приміщень, теплиць та інших об'єктів стає економічно вигідним i зручним. У кліматичних та географічних умовах України одним із перспективних напрямів використання відновлюваної енергетики 3 точки зору як екології, так i економіки $є$ застосування геотермальних i
ESM - (Engineering Systems Manager - програмний продукт для побудови систем диспетчеризації); FBD - (Function Block Diagram - графічна мова програмування).

гідротермальних теплонасосних систем (ГеоТС, ГідроТС). ГідроТС поділяються на системи відкритого, та закритого типу.

В ГеоТС первинну енергію, необхідну для роботи теплового насоса, отримують за допомогою грунтових теплообмінників, встановлених горизонтально в траншеї або вертикально у свердловини, що входять до складу системи вилучення низькопетенційної відновлюваної енергії 3 грунту. В ГідроТС закритого типу первинну енергію, необхідну для роботи теплового насоса, отримують за допомогою гідротермальних теплообмінників, 
встановлених у відкриту водойму або водоносний горизонт, в яких по замкнутому контуру циркулює теплоносій. А в ГідроТС відкритого типу система відбору низькопотенційної теплової енергії води підземних горизонтів складаються 3 одної або декількох пар свердловин (видобувної та поглинальної) [5].

Використання

низькотемпературної геотермальної енергії малих глибин (до 300 м) можна розглядати як певний технікоекономічний феномен або справжню революцію в системі теплозабезпечення. Протягом останніх 20 років у світі було науково обгрунтовано та розроблено технологію та побудовано велику кількість діючих систем теплопостачання на теплових насосах.

Досвіду використання теплонасосних систем в Україні та світі, де як первинне джерело енергії використовується низькопотенційна енергія приповерхневих шарів Землі, присвячено велику кількість досліджень. В роботах $[4,7,9$, 14] аналізується ефективність різних типів теплонасосних систем. Аналізу ефективності використання теплового потенціалу довкілля та верхніх шарів Землі присвячені роботи $[5,13,15$, 16]. Аналіз гідрогеологічних i геотермічних характеристик геотермальних об'єктів України виконано в роботі [1]. У роботі [11] запропоновано новий підхід до оцінки ефективності теплових насосів та досліджено ефективні напрямки інвестування в галузі геотермальної енергетики. Останніми роками розпочато активні науково-дослідницькі роботи 3 вивчення фізичних особливостей та енергетичної ефективності використання перших від поверхні водоносних горизонтів для тепло- та холодопостачання [8, 10, 16].

Основна відмінність теплового насоса від інших перетворювачів відновлюваної енергії полягає в тому, що при виробництві тепла до $80 \%$ енергії витягується 3 навколишнього середовища: грунту або води. Однак така система

має й недоліки, пов'язані з суттєвою залежністю ефективності від стабільності й температури низькопотенційного джерела тепла.

Водоносний горизонт $є$ високоефективним джерелом відновлюваної низкопотенційної енергії, однак використання таких систем багато в чому залежить від наявності відомостей щодо геологічної будови гірського масиву та гідрогеологічних параметрів і температури водоносного горизонту. Це вимагає проведення додаткових досліджень i створення науково обгрунтованих методик проєктування гідротермальних теплонасосних систем 3 урахуванням гідрогеологічних особливостей району, де планується установка даних систем.

Постановка завдання. Метою роботи $\epsilon$ проведення гідрогеологічних досліджень та визначання залежності техніко-економічних показників гідротермальної теплонасосної системи від гідрогеологічних параметрів водоносного горизонту, розкритого свердловинами, що використовуються для циркуляції води по контуру випарювальника теплового насоса та відбору низькопотенційної теплової енергії.

Відповідно до поставленої мети мають бути виконані такі завдання:

1. Загальний аналіз геотермічного режиму приповерхневої зони земної кори.

2. Визначення основних гідрогеологічних параметрів, що впливають на техніко-економічні показники гідротермальної теплонасосної системи

3. Створення методики проведення досліджень.

4. Узагальнення результатів дослідження.

5. Порівняльний аналіз теплонасосних систем 3 різними видами первинного відновлюваного джерела теплової енергії.

6. Визначення перспективи подальших наукових розробок у цьому напрямі.

Виклад

Геотермічний основного

матеріалу. режим приповерхневої зони 
(аерація й активний водообмін) земної кори (до глибини $\leq$ 100-300 м) має ряд особливостей у порівнянні 3 тепловим i температурним полем глибших горизонтів літосфери.

1. Тепловий режим зони аерації обумовлен поєднанням двох енергетичних факторів i потоків енергії: зовнішнього - за рахунок сонячного тепла, найбільш інтенсивного порівняно з іншими джерелами, і внутрішнього в результаті кондуктивного i конвективного виносу глибинного тепла надр.

2. Теплове поле приповерхневої зони відзначається найбільшою контрастністю й мінливістю в часі та просторі при загальному невисокому рівні температур. Воно істотно залежить від кліматичних факторів, що визначають температурний фон гірських порід $\mathrm{i}$ циркулюючих в зоні аерації підземних вод. Це пов'язано 3 тим, що приповерхнева частина літосфери (до глибин 200-300 м) перебуває в межах області інтенсивного впливу сонячної радіації й активного водообміну зони аерації за участю атмосферних і грунтових вод

Саме ці фактори, а також умови передачі теплоти (співвідношення кондуктивної та конвективної складових) і термічні властивості води (або льоду) й гірських порід в зоні гіпергенезу, визначають характер геотермічного (гідрогеотерміческого) режиму i його істотну залежність від кліматичних (ландшафтнокліматичних) особливостей регіонів.

Види та структура гідрогеологічних досліджень визначаються характером, масштабом і специфікою конкретних задач, що вирішуються, та складом і якістю необхідної гідрогеологічної інформації [6]. Одним 3 основних видів робіт під час проведення гідрогеологічних досліджень є спостереження за режимом підземних вод. Під режимом підземних вод розуміють зміну з часом найголовніших їхніх характеристик: глибини залягання, рівня, швидкості руху, хімічного складу, фізичних властивостей, температури тощо. Для розрахунку ефективності гідротермальної теплонасосної системи основними параметрами $є$ температура води водносного горизонту, статичний рівень та дебет свердловини [9].

На відміну від геотермальних ресурсів глибоких горизонтів (> 500-1000 м), де основні теплофізичні параметри гірських порід, форма перенесення тепла і тепловий потік пов'язані 3 внутрішніми джерелами, ресурси зони аерації (до глибин 200-300 м) обумовлені поєднанням кліматичних (ландшафтно-кліматичних) i гідрологічних факторів, 3 одного боку, та геологічних, геотермических і гідрогеологічних властивостей різновікових структурних комплексів - 3 іншого. При цьому в південних ландшафтних зонах вплив кліматичних факторів у температурний режим приповерхностной зони аерації може бути вирішальним [2].

Основними фізичними параметрами для розрахунку гідротермальних теплонасосних систем є температура води на гирлі свердловини, яка для малих глибин (до 300 м) дорівнює температурі води водоносного горизонту, а також дебет свердловини, який повинен бути постійним (стабільним) при встановленому зниженні. Вивчення температурного режиму водоносного горизонту здійснюється перш за все прямими вимірами температури у свердловинах геотермометрами різної конструкції [2].

Для проведення досліджень теплових i гідродинамічних процесів, що відбуваються в продуктивному водоносному пласті під час освоєння низькопотенційної енергії підземних вод верхніх водоносних горизонтів, в Інституті відновлюваної енергетики НАН України на прибудинковій ділянці корпусу 2, що розташований за адресою вул. Метрологічна, буд. 50, було створено експериментальну систему видобування геотермальних джерел енергії типу ГЦС (геотермальна циркуляційна система).

Експериментальна установка $\epsilon$ теплообмінним пристроєм, який складається із 
двох свердловин (№ 1 та № 8), поєднаних трубопроводами для циркуляції підземних вод між водоносним горизонтом та будівлею Інституту.

Свердловина № 1 була пробурена до глибини 57 м та розкрила водоносний горизонт у відкладах межигірської, берекської та новопетрівської світ олігоцен-міоцену (полтавська i харківська серії). Складається горизонт 3 дрібнозернистих пісків, що залягають в інтервалі глибин 34-57 м.

Свердловина № 8 була пробурена на відстані 11,5 м від свердловини № 1. Глибина свердловини - 50 м. Продуктивний водоносний горизонт відкладень межигірської, берекської та новопетрівської світ олігоцен-міоцену у свердловині № 8 розташований на глибині 3250 м. У обох свердловинах на водопідйомних трубах встановлені електрозанурювальні насоси. У свердловині № $1-2 \mathrm{~m}^{3} /$ год, у свердловині № $8-3 \mathrm{M}^{3} /$ год [10].

3 метою проведення дослідження теплового режиму гідротермальної теплонасосної системи як без навантаження, так і під час роботи на кондиціювання та опалення приміщень будівлі експериментальну систему видобування геотермальних джерел енергії нами було приєднано до теплового насоса типу вода-вода та фанкойлів. Разом вони складають експериментальну гідротермальну теплонасосну систему (рис. 1).

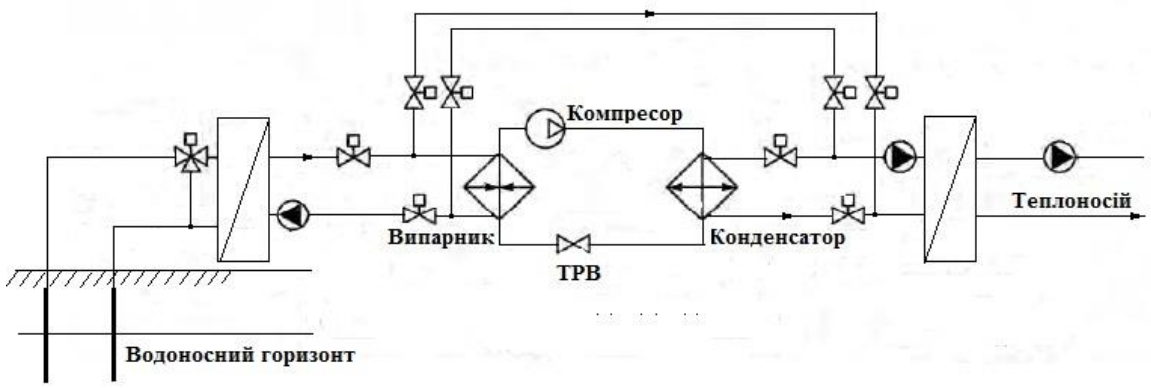

Рис. 1. Експериментальна гідротермальна теплонасосна система Інституту відновлюваної енергетики НАН України

Fig. 1. Experimental hydrothermal heat pump system of the Institute of Renewable Energy of the National Academy of Sciences of Ukraine

Склад експериментальної гідротермальної теплонасосної системи: геотермальна циркуляційна система (складається 3 двох свердловин 3 насосним обладнанням); акумулятор низькопотенційної теплової енергії ємністю $5 \mathrm{~m}^{3} \quad$ (складається 3 п’яти теплоізольованих ємностей по $1 \mathrm{~m}^{3}$ ); акумулятор теплової енергії системи опалення будівлі ємністю $3 \mathrm{~m}^{3} \quad$ (складається 3 трьох теплоізольованих ємностей по $1 \mathrm{~m}^{3}$ ); теплового насоса типу вода-вода (планується встановлення теплонасосного кластера, який поєднє декілька теплових насосів малої потужності в єдину систему). В цей час в системі використовується один тепловий насос типу вода-вода потужністю 5 КВт.

Відповідно до поставленого завдання дослідження для вимірювань температури у свердловині та в контрольних точках системи були встановлені датчики температури (термоперетворювачі опору) ТСП-204. Термоперетворювачі опору ТСП-204 внесені до Державного реєстру засобів вимірювальної техніки України за номером У246-07. Робочий діапазон вимірюваних температур - від -40 до $+270{ }^{\circ} \mathrm{C}$, показник теплової інерції не більше 6-8 c. Датчики температури встановлені у свердловину на глибині: 42, 39, 34 та 29 м, а також на впускних i випускних трубопроводах 
обох свердловин, на акумуляторі тепла, на вході й виході контуру конденсатора та контуру випарювальника теплового насоса та на магістралях подачі й возврату теплоносія 3 фанкойлів. Крім того, на магістралі подачі та возврату води зі свердловин встановлені датчики

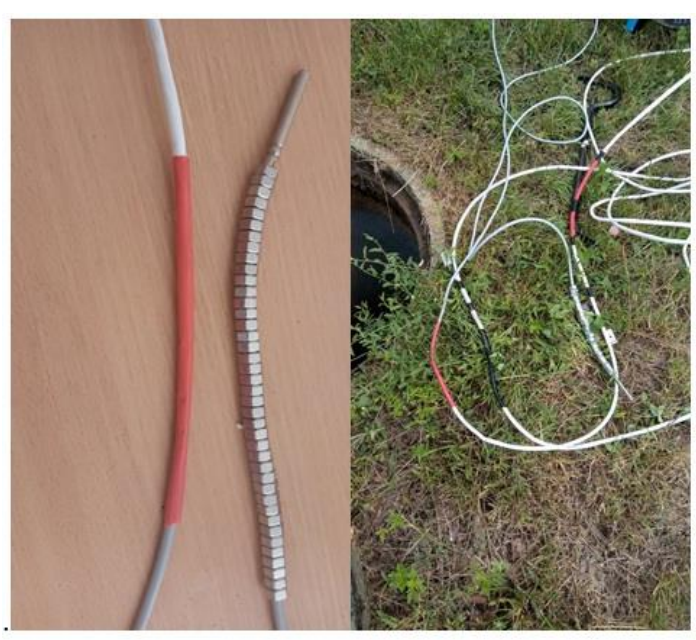

$a$ б витрати теплоносія, а на контурі конденсатора теплового насоса було встановлено пристрій контролю кількості виробленого тепла (теплолічильник) Landis Gyr Ultraheat T230 (рис. 2).
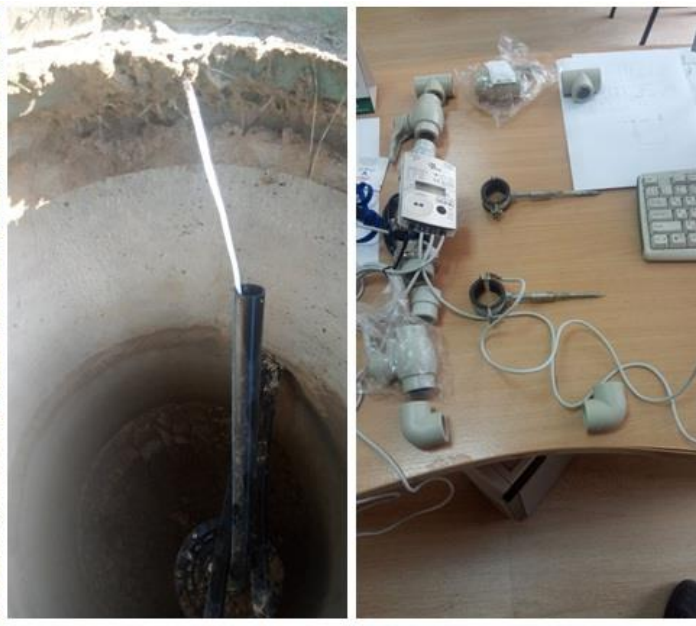

Рис. 2. Вимірювальні пристрої експериментальної гідротермальної теплонасосної системи IВЕ НАНУ: $a-$ занурюваний датчик температури з грузилом; $\sigma$ - вимірювальна коса з встановленими термоперетворювачами опору ТСП-204; в - монтаж вимірювальної коси у свердловину; г - теплолічильник Landis Gyr Ultraheat T230

Fig. 2. Measuring devices of the experimental hydrothermal heat pump system of IRE NAS of Ukraine: a - submersible temperature sensor with sinker; $\sigma$ - measuring braid with installed resistance thermocouples TSP-204; 8 - method of mounting the measuring braid in the well 2 - heat meter Landis Gyr Ultraheat T230

3 урахуванням особих умов проведення вимірювань у свердловині (підвищена вологість і велика глибина) та необхідності розміщення до восьми датчиків на одній косі було використано провід 3 восьма жилами та металевим екраном типу $4 * 2 * 0,51$ (SF/UTP-cat.5E ). Також місця можливого контакту проводу 3 водою було ізольовано в гумований кожух, а місця пайки контактів датчика температури (термоперетворювача опору) залито епоксидною смолою.

Для збору даних 3 вимірювальних пристроїв було використано контролер MAXYCON FLEXY приєднаний до персонального комп'ютера через шлюз USB i RS485 , призначений для прийому, перетворення й передачі цифрової інформації між цифровими лініями по інтерфейсу RS-485 та протоколу
Modbus-RTU. Інформація 3 датчиків знімалася автоматично з часовим інтервалом п'ять секунд.

За допомогою розробленої автором інтерактивної системи диспетчеризації на базі програмного продукту ESM (Engineering Systems Manager) 3 використанням мови програмування FBD (Function Block Diagram|Continuous Function Chart) було забезпечено збір даних 3 вимірювальних пристроїв 3 подальшою обробкою та записом в архів для їх інтерпретації та виведення на монітор комп'ютера програмою візуалізації в реальному часі. Контролер MAXYCON FLEXY разом з блоками розширення має можливість знімати показники більш ніж 36 каналів інформації, а розроблене спеціальне програмне забезпечення використовується також для дистанційного керування системою як в автономному, так і ручному режимі (рис. 3). 


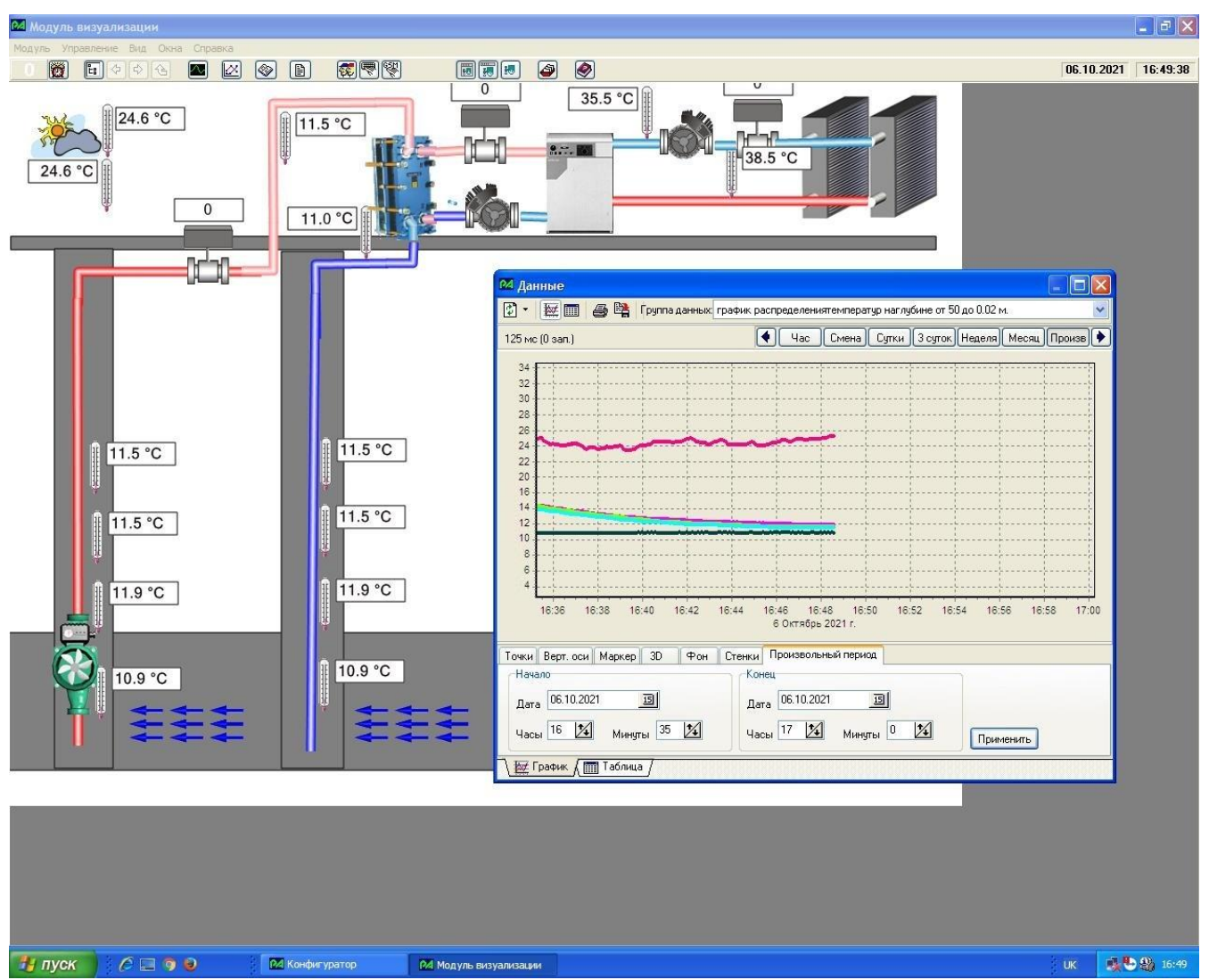

Рис. 3. Зображення екрана компьютера з відображенням інтерфейсу системи диспетчеризації на базі програмного продукту ESM (Engineering Systems Мanager) експериментальної гідротермальної теплонасосної системи IBE НАНУ

Fig. 3. Image of the computer screen with the display of the interface of the dispatching system based on the software product

ESM (Engineering Systems Manager) of the experimental hydrothermal heat pump system of IRE NAS of Ukraine

Температурний режим підземних вод аерації та конвективного переносу тепла зі формується під впливом широкого спектра спадними потоками підземних вод [3].

факторів, серед яких: кліматичні зміни,

Режимні спостереження рівнів і температур метеорологічні явища, гідрогеологічні процеси й фізико-хімічні перетворення, тектонічні та сейсмічні процеси, припливи і багато інших. Найістотніші зміни температури підземних i грунтових вод пов'язані здебільшого 3 добовими, сезонними та багаторічними коливаннями температур повітря біля поверхні Землі, що накладаються на постійний тепловий потік, який надходить $з$ надр Землі. Відповідно до цього у вертикальному розрізі літосфери нижче поверхні Землі можуть бути виділені послідовно: зона добових, річних i багаторічних коливань температури; зона постійних температур нейтральний шар. Поширення атмосферних коливань температури у верхню частину літосфери здійснюється шляхом молекулярнодифузійного переносу тепла через породи зони водоносного горизонту з інтервалом вимірювань сім діб в місці проведення дослідження були розпочаті з моменту побудови експериментальної системи видобування геотермальних джерел енергії. Для вимірювань використовувалися переносні вимірювачі. Разом 3 тим дані вимірювання мають велику похибку за рахунок суб'єктивної оцінки параметра, що вимірюється оператором, та великої дискретизації виконаних вимірювань.

Запроваджена 3 червня 2021 року атоматизована комп'ютерна система моніторингу забезпечила системність вимірювань, їх високу точність та дискретність - від 10 до 5 с.

Прийнятий інтервал часу запису даних (від 10 до 5 с) забезпечує можливість вивчення добової динаміки показників. 
Важливо підкреслити, що вивчення режиму підземних вод за допомогою розташованих в свердловинах датчиків високої чутливості та відносно високою частотою зчитування даних, дозволяє отримати якісно нову інформацію про періодичність гідрогеодінамічних i фізикохімічних процесів.

Аналіз накопичених за період спостережень 31 червня 2021 року по 9 жовтня 2019 року даних температури повітря та води у свердловині виявив наявність їх спрямованого зменшення.

За період спостережень зміни температур повітря на глибіні 39, 34 і 29 м становили $0,3^{\circ} \mathrm{C}$, а зміни температури води на глибіні 42 м (на 1,7 м нижче рівня води у свердловині) становили $0,6^{\circ} \mathrm{C}$.

Відхилення від лінійного тренда температур повітря у свердловині з амплітудою $0,3{ }^{\circ} \mathrm{C}$ i води $0,6{ }^{\circ} \mathrm{C}$ дозволяють припустити наявність сезонної компоненти у варіаціях цих характеристик. Прямий кореляційний зв'язок між варіаціями температур повітря $\mathrm{i}$ води $\mathrm{y}$ свердловині, а також відсутність фазового зсуву між ними, свідчать про вплив сезонних атмосферних змін температур на глибинах залягання водоносного горизонту (рис. 4).
Наявність сезонних варіацій температур підземних вод вказує на те, що зона постійних температур - нейтральний шар - розташована глибше. Характеристики досягають свого максимуму в ранковий i вечірній час 3 інтервалом, близьким до 12 год.

Зіставлення графіків добової динаміки температур повітря і води (частота замірів кожні 5 с), представлених на рис. 5, показало, що спостерігається синхронний зв'язок між ними протягом доби, а також фазовий зсув між ними, що дорівнює 7 год 30 хв.

Найчастіше добові коливання температури виявляються при глибинах залягання підземних вод, які не перевищують декількох метрів. Прояв добових варіацій температур водоносного горизонту у відкладах межигірської, берекської та новопетрівської світ олігоцен-міоцену може бути обумовлено процесами перетікання грунтових вод i скидання їх численними дренажними свердловинами в пласт-колектор та $\epsilon$ показником порушення температурного режиму, що, найімовірніше, вказує на техногенний вплив у межах ділянки дослідження.

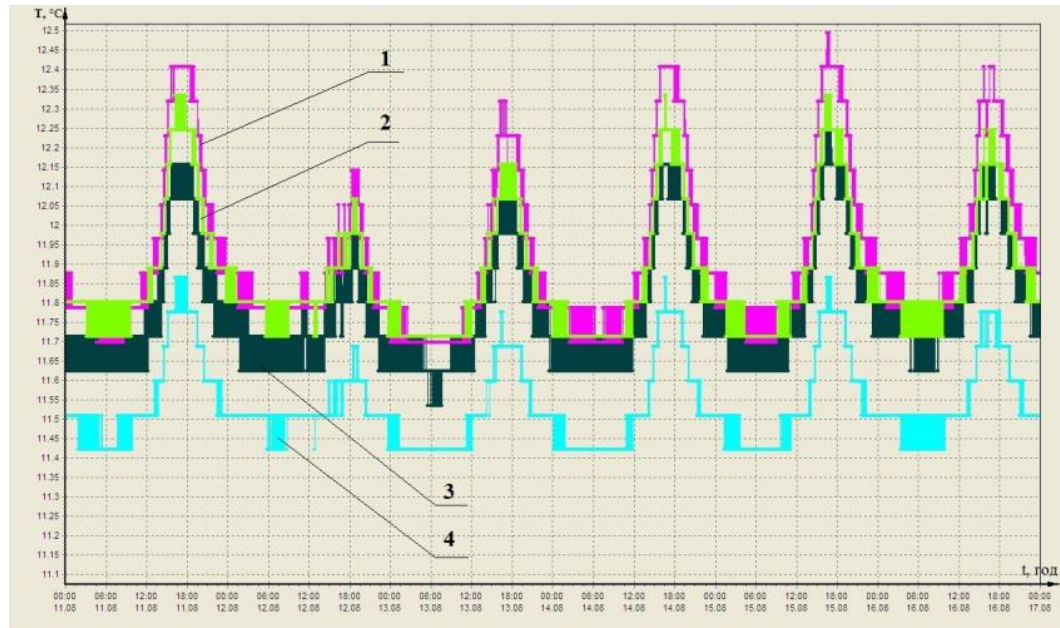

Рис. 4. Графік зміни температури у свердловині: 1 - температура у свердловині на глибіні 39 м; 2 - температура у свердловині на глибіні 34 м; 3 - температура у свердловині на глибіні 42 м (на 1,7 м нижче рівня води у свердловині); 4 - температура у свердловині на глибіні 29 м

Fig. 4. Graph of changes temperatures in the well: 1 - temperature in the well at a depth of $39 \mathrm{~m} ; 2$ - temperature in the well at a depth of $34 \mathrm{~m} ; 3$ - temperature in the well at a depth of $42 \mathrm{~m}(1.7 \mathrm{~m}$ below the water level in the well); 4- temperature in the well at a depth of $29 \mathrm{~m}$. 


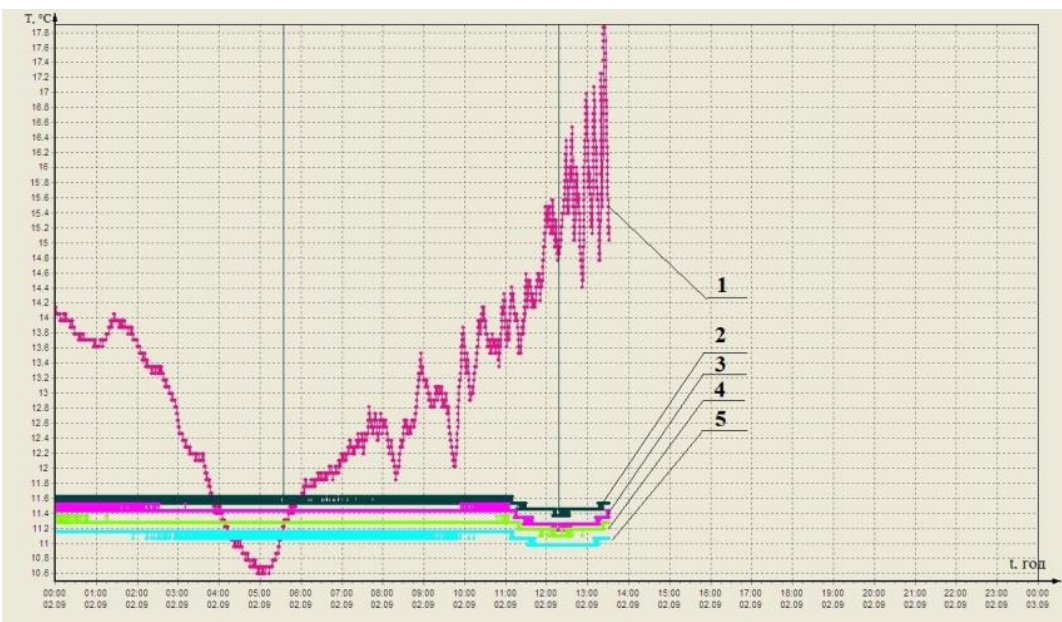

Рис. 5. Графік зміни температури повітря та води в свердловині: 1 - температура повітря (0,5 м над землею);

2 - температура у свердловині на глибіні 42 м (на 1,7 м нижче рівня води у свердловині);

3 - температура у свердловині на глибіні 39 м; 4 - температура у свердловині на глибіні 34 м; 5 - температура у свердловині на глибіні 29 м

Fig. 5. Graph of changes in air and water temperature in the well: 1- air temperature ( $0.5 \mathrm{~m}$ above the ground); 2 temperature in the well at a depth of $42 \mathrm{~m}(1.7 \mathrm{~m}$ below the water level in the well); 3 - temperature in the well at a depth of $39 \mathrm{~m} ; 4$ - temperature in the well at a depth of $34 \mathrm{~m} ; 5$ - temperature in the well at a depth of $29 \mathrm{~m}$.

Разом 3 тим експериментально отримані данні в місті розташування об'єкту дослідження, а саме температура води на гирлі свердловин № 1 та № 8 (яка залежить від температури водоносного горизонту) та дебіт свердловини (який у безнапірних свердловинах визначается потужностю насосного обладнання та залежить від динамічного рівня свердловини та зниження), $\epsilon$ достатніми для ефективної та стабільної роботи гідротермальної теплонасосної системи відбору низькопотенційної теплової енергії води підземних горизонтів.

Для визначення ефективності роботи гідротермальної теплонасосної системи відбору низькопотенційної теплової енергії води підземних горизонтів IBE НАНУ в порівнянні 3 аналогічною гідротермальною теплонасосною системою з гідротермальним теплообмінником, встановленим у відкриту водойму та геотермальною теплонасосною системою 3 грунтовими теплообмінниками, встановленими вертикально у свердловини, були використані експериментальні та аналітичні данні, представлені в роботі [16], де автор наводить порівняння ефективності геотермальної та гідротермальної енергетичних систем, спроектованих і змонтованих в Українському державному геологорозвідувальному інституті (УкрДГРІ).

Для виконання порівняльного аналізу теплонасосних енергетичних систем було прийнято критерії, в яких враховані як фізичні параметри, так і техніко-економічні показники теплових насосів (ТН) [11]:

1. Теплова продуктивність.

2. Коефіцієнт перетворення теплової енергії.

3. Діапазон температур ефективної роботи теплового насоса.

4. Питома вартість на 1 кВт виробленої теплоти.

Основним показником ефективності теплового насоса $\epsilon$ коефіцієнт трансформації (коефіцієнт перетворення теплової енергії) $\varphi_{T}$.

$$
\varphi_{T}=\frac{Q_{1}}{N}=\frac{\left(Q_{2}+N\right)}{N}=\frac{T_{2}}{\left(T_{2}-T_{11}\right)},
$$

де $Q_{1}-$ теплова продуктивність ТН, Вт; $N-$ потужність компресора, Вт; $T_{2}-$ температура теплоносія на виході 3 конденсатора, K; $T_{11}-$ температура теплоносія на вході в випарювальник, К.

Дійсний коефіцієнт трансформації теплового насоса $\varphi$ може мати вигляд 


$$
\varphi=\varphi_{T} \eta_{T H}
$$

де $\eta \mathrm{TH}$ - коефіцієнт втрат, що враховує реальні процеси, які здійснюються робочим тілом в ТН [12].

В ході проведення експерименту попередньо задані температурні параметри контуру конденсатора відповідно до методики проведення дослідження залишалися незмінними, а теплове навантаження було стабільним. Температура теплоносія на вході у випарювальник безпосередньо залежить від параметрів відновлюваного джерела. Тепловий режим грунту приповерхневих шарів Землі має вікову, багаторічну, річну й добову циклічність, пов'язану зі зміною режимів інсоляції та випромінювання. Головним джерелом теплової енергії, що надходить у грунт, $є$ сонячна радіація. Незначна кількість тепла надходить у грунт із глибинних шарів Землі, а також утворюється внаслідок розкладу органічних речовин.

Тепловий режим води у водоймі визначається декількома процесами, які відбуваються одночасно; це сонячна радіація, випаровування, теплообмін 3 атмосферою, перенос тепла течіями, турбулентним перемішуванням вод та інші. Зазвичай прогрівання води відбувається зверху вниз.

Тепловий режим води у водоносному горизонті залежить від геотермальних особливостей району. Він відображає вікові, тектонічні, літологічні й гідродинамічні особливості водоносних горизонтів та $\epsilon$ результатом впливу декількох природних i техногенних факторів, що діють одночасно, а саме таких, як сонячна радіація, випаровування, теплообмін 3 грунтом, перенос тепла, турбулентне перемішування вод, умови залягання водоносного горизонту, живлення i дренажу, а також клімат, біосферний та антропогенний вплив та інші.

У процесі проведення дослідження на трьох енергетичних установках 3 системами відбору первинної низькопотенційної енергії різних конструкцій, але 3 однаковими за потужністю тепловими насосами, були отримані дані річних змін температури у водоймі та у свердловинах, змін температури на вході у випарювальник i конденсатор і на виході 3 випарювальника й конденсатора, а також кількості протоку теплоносія в одиницю часу (табл. 1).

Таблиця 1. Температури на вході й виході з випарювальника і конденсатора та кількості протоку теплоносія в одиницю часу для теплонасосних систем

Table 1. Temperatures at the inlet and outlet of the evaporator and condenser and the amount of coolant flow per unit time for heat pump systems

\begin{tabular}{|c|c|c|c|c|c|c|}
\hline $\begin{array}{c}\text { Джерело } \\
\text { теплової } \\
\text { енергії }\end{array}$ & $\begin{array}{c}\text { Температура на } \\
\text { вході у } \\
\text { випарювальник, } \\
{ }^{\circ} \mathrm{C}\end{array}$ & $\begin{array}{c}\text { Температура на } \\
\text { виході } 3 \\
\text { випарювальника, } \\
{ }^{\circ} \mathrm{C}\end{array}$ & $\begin{array}{c}\text { Продуктивність } \\
\text { циркуляційного } \\
\text { насоса по } \\
\text { контуру } \\
\text { випарювальника, } \\
\mathrm{M}^{3} / \text { год }\end{array}$ & $\begin{array}{c}\text { Температура } \\
\text { на вході у } \\
\text { конденсатор, } \\
{ }^{\circ} \mathrm{C}\end{array}$ & $\begin{array}{c}\text { Температура } \\
\text { на виході з } \\
\text { конденсатора, } \\
{ }^{\circ} \mathrm{C}\end{array}$ & $\begin{array}{c}\text { Продуктивність } \\
\text { циркуляційного } \\
\text { насоса по } \\
\text { контуру } \\
\text { конденсатора, } \\
\mathrm{M}^{3} / \text { год }\end{array}$ \\
\hline $\mathrm{A}$ & 12 & 9,1 & 3,2 & 45 & 36,5 & 1,4 \\
\hline Б & 11 & 8,1 & 3,2 & 45 & 36,5 & 1,4 \\
\hline $\mathrm{B}$ & 7 & 4,2 & 3,2 & 45 & 36,5 & 1,4 \\
\hline
\end{tabular}

А - геотермальна теплонасосна система 3 теплообмінниками, встановленими у свердловини глибиною 50 м; Б гідротермальна теплонасосна системи з забором води зі свердловин глибиною 50 м, якими розкрито водоносний горизонт; В - гідротермальна теплонасосна система з теплообмінником, зануреним у водойму глибиною 2,5 м

A - geothermal heat pump system with heat exchangers, installed in wells with a depth of $50 \mathrm{~m}$; B - hydrothermal heat pump system with water intake from wells with a depth of $50 \mathrm{~m}$, which opened the aquifer; B - hydrothermal heat pump system with a heat exchanger immersed in a reservoir with a depth of $2.5 \mathrm{~m}$ 
Експериментально встановлено, що для геотермальної теплонасосної системи 3 теплообмінниками, встановленими у свердловину глибиною $50 \mathrm{M}$, температура теплоносія на вході у випарювальник $\epsilon$ стабільною та становить в середньому $12{ }^{\circ} \mathrm{C}$. Під час дослідження були встановлені незначні коливання на вході у випарювальник в діапазоні 0,5-2 ${ }^{\circ} \mathrm{C}$, які залежать тільки від навантаження на систему і не залежать від часу доби та пори року.

Встановлено також, що для гідротермальної теплонасосної системи 3 теплообмінником, зануреним у водойму глибиною 2,5 м, температура теплоносія на вході в конденсатор теплового насоса коливається в діапазоні від 2 до $5^{\circ} \mathrm{C}$ у січні-лютому, у листопаді-квітні становить $10-14{ }^{\circ} \mathrm{C}$, а в червнісерпні, при температурі води у водоймі $24-27^{\circ} \mathrm{C}$, температура теплоносія на вході у випарювальник не підіймається вище $20{ }^{\circ} \mathrm{C}$.

Експериментально встановлено, що для гідротермальної теплонасосної системи з забором води зі свердловин, якою розкрито водоносний горизонт, температура води на глибині 50 м є досить стабільною у часі та становить у середньому $11^{\circ} \mathrm{C}$. Під час дослідження були виявлені незначні сезонні коливання температури води $\left(0,5-3^{\circ} \mathrm{C}\right)$ на виході зі свердловини. Теоретично обгрунтовано, що такі коливання температури води (теплоносія) можливі за рахунок теплообміну між стінками труби, якою підіймається вода, та грунтом вище границі промерзання (1-2 м).

На основі експериментально отриманих даних витрат теплоносія по контуру конденсатора i значень температур на вході й виході 3 конденсатора теплового насоса розраховане значення теплової продуктивності всієї енергетичної системи в цілому, яка склала 14 кВт за теплом для кожної з систем.

Було розраховано коефіцієнти трансформації для кожної 3 теплонасосних систем для трьох зимових місяців року. Крім того, для порівняння обох гідротермальних систем 3 геотермальною теплонасосною системою були використані дані, отримані під час попередніх досліджень [13].

Діапазон температур ефективної роботи теплового насоса по контуру конденсатора визначається системою опалення будівлі, а ефективність системи - зворотно пропорційна температурі теплоносія на виході з конденсатора ТН. При проведенні експерименту в обох системах температура на виході 3 конденсатора встановлювалася однаковою і становила $45^{\circ} \mathrm{C}$. При цьому продуктивність циркуляційного насоса, що забезпечує циркуляцію теплоносія від випарювальника до системи теплозабезпечення будівлі, становила $1,4 \mathrm{~m}^{3} /$ год.

Діапазон температур ефективної роботи теплового насоса по контуру випарювальника визначається джерелом низькопотенційної енергії й установлюється на підставі аналітичних розрахунків залежно від середньої температури теплоносія на вході у випарювальник. Для геотермальної теплонасосної системи 3 теплообмінниками, встановленими у свердловини глибиною 50 м, та гідротермальної теплонасосної системи 3 забором води зі свердловин глибиною 50 м діапазон температур ефективної роботи становить $8-13{ }^{\circ} \mathrm{C}$, а для гідротермальної теплонасосної системи 3 теплообмінником, зануреним у водойму глибиною 2,5 м, діапазон температур ефективної роботи становить $5-10{ }^{\circ} \mathrm{C}$.

Питома вартість системи на 1 кВт виробленої теплової енергії для систем, що досліджуються, відрізняється тільки вартістю монтажу колектора зоя зору низькотемпературної теплової енергії. Для гідротермальної теплонасосної системи з забором води зі свердловин глибиною 50 м загальна вартість монтажу в цінах 2021 року становить 50-70 тис. гривень, для геотермальної теплонасосної системи 3 теплообмінниками, встановленими у свердловини глибиною 50 м, - 
100-140 тис. гривень, а для гідротермальної теплонасосної системи 3 теплообмінником, зануреним у водойму глибиною 2,5 м,- $10-$ 20 тис. гривень. 3 урахуванням вартості теплового насоса, що становить за цінами 2021 року 210 тис. гривень, відповідно вартість системи на 1 кВт виробленої теплової енергії становитиме в середньому 19,3 тис. гривень, 23,4 тис. гривень, та 16 тис. гривень.

\section{Висновки:}

1. Встановлено, що важливу роль у визначенні факторів, які впливають на температурний режим водоносного горизонту, відіграє вивчення трендів зміни з часом основних гідрологічних параметрів. Встановлені за період спостережень зміни температур, а саме незначні за амплітудою їх сезонні й добові варіації, $\epsilon$ показником порушення температурного режиму i вказують на техногенний вплив у межах ділянки досліджень.

2. Обгрунтовано, що для ефективного використання водоносного горизонту як природного акумулятора теплової енергії необхідно проведення попередніх гідрогеологічних досліджень та якісне вивчення геоморфологічних, геологічних та гідрогеологічних параметрів ділянки проведення бурових робіт.

\section{3. Аналітично}

експериментально обгрунтовано підтверджено, геотермальні теплонасосні системи з вертикально встановленим у свердловину колектором на глибину понад 15 м потребують, у порівнянні 3 аналогічними гідротермальними системами, вдвічі більших початкових інвестицій. При цьому мають аналогічний гідротермальним системам високий коефіцієнт перетворення теплової енергії (коефіцієнт трансформації ), який у зимовий період дорівнює 4,5.

4. Експериментально підтверджено, що приповерхневі грунтові води $\epsilon$ ефективним джерелом низькопотенційного тепла для теплових насосів, оскільки їх температура протягом всього року перебуває в діапазоні від +8 до $+12{ }^{\circ} \mathrm{C}$. Крім того, додатковою перевагою використання грунтових вод $\epsilon$ можливість їх ефективного застосування для кондиціонування в літній час без застосування теплового насоса.

5. Мають перспективу подальші експериментальні дослідження впливу дебіту та динаміного рівня свердловини на стабільність та ефективність роботи гідротермальної теплонасосної системи.

1. Барило А.А. Аналіз гідрогеологічних i геотермічних характеристик геотермальних об'єктів України. Відновлювана енергетика. 2020. № 1(60). С. 74-84. https://doi.org/10.36296/1819-8058.2020.1(60).74-85

2. Богуславский Э.И. Освоение тепловой энергии недр. Санкт-Петербург. Наукоемкие технологии. 2020. 435 с.

3. Диденко Д.Ю., Черкез Е.А. Температурный режим водоносного горизонта в понтических известняках по данным мониторинга в катакомбах одессы. Подземные сооружения Одессы и Одесской области: Сборник материалов II-й научно-практической конференции. Одесса. 2019. C. $127-134$.

4. Долинский А.А., Драганов Б.Х. Тепловые насосы в системе теплоснабжения зданий. Промышленная теплотехника. 2008. т. 30. № 6. С. 71-83.

5. Зур'ян О.В., Олійніченко В.Г. Гідротермальна система отримання теплової енергії, фізичні процеси, ефективність. Вісник Вінницького політехнічного інституту. 2021. № 4. C. 41-47. https://doi.org/10.31649/1997-9266-2021157-4-40-46

6. Корнєєнко С.В. Методика гідрогеологічних досліджень. Підручник. КНУ ім. Тараса Шевченка. Київ. 2015. $275 \mathrm{c}$.

7. Кудря С.О. Відновлювані джерела енергії. IBE НАН України. Київ. 2020. 354 с

8. Малкін Е.С., Кулінко С.О. Перспективи та аспекти застосування систем теплохолодопостачання, які використовують приповерхневі шари води в якості теплового акумулятора. Вентиляція, освітлення та теплогазопостачання. 2014. Вип. № 17. С. 63-69.

9. Морозов Ю.П., Барило А.А., Чалаєв Д.М., Добровольський М.П. Енергетична ефективність використання перших від поверхні водоносних горизонтів для тепло- $\mathrm{i}$ хладопостачання. Відновлювана енергетика. 2019. № 2. С. 70 78. DOI: https://doi.org/10.36296/1819-8058.2019.2(57).70-78

10. Морозов Ю.П., Чалаєв Д.М., Олійніченко В.Г., Величко В.B. Експериментальне дослідження добового акумулювання холоду шляхом використання води підземних горизонтів м. Києва. Відновлювана енергетика. 2019. № 3. С. 67-77. DOI: https://doi.org/10.36296/1819-8058.2019.3(58).67-77

11. Олійніченко В.Г., Марченко Н.В., Кушнір І.О. Ефективні напрямки інвестування в галузі геотермальної енергетики. Відновлювана енергетика. 2017. № 3. С. 73-79. 
12. Fedyanin V.Y., Miheev D.D. The method of calculating the heat flow in the soil heat exchanger, Gorizontyi obrazovaniya. Materialyi 61-y Nauchno-tehnicheskoy konferentsii studentov, aspirantov i professorskoprepodavatelskogo sostava. Russia. 2005 vol. 11. Pp. 12-15.

13. Goshovskiy S.V., Zurian O.V. Human-induced load on the environment when using geothermal heat pump wells. Journal of Geology. Geography and Geoecology. 2020. № 1. C. 57-68. https://doi.org/10.15421/112006

14. Lund J., Sanner B., Rybach L., Curtis R., Hellstrom $G$. Geothermal (ground-source) heat pumps a world overview. GHC bulletin. 2004. Vol. 9. Pp. 1-10.

15. Zhu Ke, Blum Philipp, Ferguson Grant, Balke Klaus-Dieter, Bayer Peter. The geothermal potential of urban heat islands. 2010. Environ. Res. Lett. No. 5. Pp. 1-6. http://dx.doi.org/10.1088/1748-9326/6/1/019501

16. Zurian O.V. Comparison of efficiency of geothermal and hydrothermal energy systems. XIX International Multidisciplinary Scientific GeoConference SGEM. Renewable Energy Sources and Clean Tech. Varna. Bulgaria. 2019. C. 83-90. https://doi.org/10.5593/sgem2019/4.1/S17.011

\section{REFERENCES}

1. Barylo A.A. Analiz gidrogeologichnyh i geotermichnyh xarakterystyk geotermalnyh obyektiv Ukrayiny. [Analysis of hydrogeological and geothermal characteristics of geothermal objects of Ukraine]. Vidnovluvana energetika. 2020. No. 1(60). Pp. 74-84. https://doi.org/10.36296/18198058.2020.1(60).74-85 [in Ukrainian].

2. Boguslavskij E.I. Osvoenie teplovoj energii nedr. Sankt-Peterburg. [Development of thermal energy of the subsoil]. Naukoemkie tekhnologii. 2020. 435 p. [in Russian].

3. Didenko D.Yu., Cherkez E.A. Temperaturnyj rezhim vodonosnogo gorizonta $\mathrm{v}$ ponticheskih izvestnyakah po dannym monitoringa $\mathrm{v}$ katakombah odessy. [The temperature regime of the aquifer in pontic limestones according to monitoring data in the catacombs of Odessa]. Podzemnye sooruzheniya Odessy i Odesskoj oblasti: Sbornik materialov II-j nauchno-prakticheskoj konferencii. Odessa. 2019. Pp. 127-134. [in Russian].

4. Dolinskij A. A. Draganov B.H. Teplovye nasosy v sisteme teplosnabzheniya zdanij. [Heat pumps in the heating system of buildings]. Promyshlennaya teplotekhnika. 2008. t. 30. No. 6. Pp. 71-83. [in Russian].

5. Zurian O.V. Olijnichenko V.G. Gidrotermalna systema otrymannya teplovoyi energiyi, fizychni procesy, efektyvnist. [Hydrothermal system of thermal energy production, physical processes, efficiency]. Visnyk Vinnyckogo politexnichnogo instytutu. 2021. No. 4. Pp. 41-47.

https://doi.org/10.31649/1997-9266-2021-157-4-41-47 [in Ukrainian].

6. Kornyeyenko S.V. Metodyka gidrogeologichnyh doslidzhen. [Methods of hydrogeological research]. Pidruchnyk. KNU im Tarasa Shevchenko Kyiv. 2015. 275 p. [in Ukrainian].
7. Kudrya S.O. Vidnovlyuvani dzherela energiyi. [Renewable energy sources]. IVE NAN Ukrayiny. Kyiv. 2020. 354 p. [in Ukrainian].

8. Malkin E.S., Kulinko Ye.O. Perspektyvy ta aspekty zastosuvannya system teploxolodopostachannya, yaki vykorystovuyut prypoverxnevi shary vody $\mathrm{v}$ yakosti teplovogo akumulyatora. [Prospects and aspects of application of heat and cold supply systems that use the surface layers of water as a heat accumulator]. Ventylyaciya, osvitlennya ta teplogazopostachannya. 2014. No. 17. Pp. 63-69. [in Ukrainian].

9. Morozov Yu.P., Barylo A.A., Chalayev D.M., Dobrovolskyj M.P. Energetychna efektyvnist vykorystannya pershyh vid poverxni vodonosnyh goryzontiv dlya teplo- i xladopostachannya. [Energy efficiency of using the first aquifers from the surface for heat and cold supply]. Vidnovluvana energetika. 2019. No. 2. Pp. 70-78.

DOI: https://doi.org/10.36296/1819-8058.2019.2(57).70-78

[in Ukrainian].

10. Morozov Yu.P., Chalayev D.M., Olijnichenko V.G., Velychko V.V. Eksperymentalne doslidzhennya dobovogo akumulyuvannya xolodu shlyaxom vykorystannya vody pidzemnyh goryzontiv m. Kyeva. [Experimental study of daily accumulation of cold by using water of underground horizons of Kyiv]. Vidnovluvana energetika. 2019. No. 3. Pp. 67-77. DOI: https://doi.org/10.36296/1819-8058.2019.3(58).67-77

[in Ukrainian].

11. Olejnychenko V.G., Marchenko N.V., Kushnir I.O. Efektyvni napryamky investuvannya $\mathrm{v}$ galuzi geotermalnoyi energetyky. [Effective areas of investment in the field of geothermal energy]. Vidnovluvana energetika. 2017. No. 3. Pp. 73-79. [in Ukrainian].

12. Fedyanin V.Y., Miheev D.D. The method of calculating the heat flow in the soil heat exchanger, Gorizontyi obrazovaniya. Materialyi 61-y Nauchno-tehnicheskoy konferentsii studentov, aspirantov i professorskoprepodavatelskogo sostava. Russia. 2005. Vol. 11. Pp. 12-15. [in English].

13. Goshovskiy S.V., Zurian O.V. Human-induced load on the environment when using geothermal heat pump wells. Journal of Geology. Geography and Geoecology. 2020. No. 1. Pp. 57-68. https://doi.org/10.15421/112006 [in English]. 14. Lund J., Sanner B., Rybach L., Curtis R., Hellstrom $G$. Geothermal (ground-source) heat pumps a world overview. GHC bulletin. 2004. Vol. 9. Pp. 1-10. [in English].

15. Zhu Ke, Blum Philipp, Ferguson Grant, Balke Klaus-Dieter, Bayer Peter. The geothermal potential of urban heat islands. 2010. Environ. Res. Lett. No. 5. Pp. 1-6. http://dx.doi.org/10.1088/1748-9326/6/1/019501 [in English].

16. Zurian O.V. Comparison of efficiency of geothermal and hydrothermal energy systems. XIX International Multidisciplinary Scientific GeoConference SGEM. Renewable Energy Sources and Clean Tech. Varna. Bulgaria. 2019. Pp. 83-90. https://doi.org/10.5593/sgem2019/4.1/S17.011 [in English].

Стаття надійшла до редакції 11.10.21 Остаточна версія 30.11.21 